\title{
Gastric stem cells and gastric cancer stem cells
}

\author{
Myoung-Eun $\mathrm{Han}^{1,2}$, Sae-Ock $\mathrm{Oh}^{1,2}$ \\ ${ }^{1}$ Department of Anatomy, Pusan National University School of Medicine, ${ }^{2}$ Medical Research Center for Ischemic Tissue Regeneration, Pusan National \\ University, Yangsan, Korea
}

\begin{abstract}
The gastric epithelium is continuously regenerated by gastric stem cells, which give rise to various kinds of daughter cells, including parietal cells, chief cells, surface mucous cells, mucous neck cells, and enteroendocrine cells. The self-renewal and differentiation of gastric stem cells need delicate regulation to maintain the normal physiology of the stomach. Recently, it was hypothesized that cancer stem cells drive the cancer growth and metastasis. In contrast to conventional clonal evolution hypothesis, only cancer stem cells can initiate tumor formation, self-renew, and differentiate into various kinds of daughter cells. Because gastric cancer can originate from gastric stem cells and their self-renewal mechanism can be used by gastric cancer stem cells, we review here how critical signaling pathways, including hedgehog, Wnt, Notch, epidermal growth factor, and bone morphogenetic protein signaling, may regulate the self-renewal and differentiation of gastric stem cells and gastric cancer stem cells. In addition, the precancerous change of the gastric epithelium and the status of isolating gastric cancer stem cells from patients are reviewed.
\end{abstract}

Key words: Gastric stem cell, Gastric cancer stem cell, Self-renewal, Cell differentiation

Received November 30, 2012; Revised January 14, 2013; Accepted January 23, 2013

\section{Introduction}

Recently, a cancer stem cell hypothesis was introduced to explain the heterogeneity of cancer cells [1-3]. In contrast to conventional stochastic theory, the cancer stem cell hypothesis suggests that only cancer stem cells can initiate tumor formation, self-renew, and differentiate. The differentiated daughter cells, however, can only proliferate transiently, indicating the presence of hierarchical organization among cancer cells. Cancer stem cells have been shown to drive the growth and metastasis of cancer cells. Moreover, cancer stem cells are chemoresistant and radioresistant compared with the differentiated daughter cells.

Gastric cancer is the second leading cause of cancer deaths worldwide [4]. Despite advances in various diagnostic tools,

\footnotetext{
Corresponding author:

Sae-Ock Oh

Department of Anatomy, Pusan National University School of Medicine, 49 Busandaehak-ro, Yangsan 626-815, Korea

Tel: +82-51-510-8045, Fax: +82-51-510-8049, E-mail: hedgehog@pusan. ac.kr

\section{Copyright (C) 2013. Anatomy \& Cell Biology}

including endoscopy, the 5-year survival rate among gastric cancer patients is still less than $40 \%$, and this low survival rate is mainly due to relapse and metastasis [5]. Gastric cancer has been classified into 2 histological types: intestinal and diffuse. The intestinal type is characterized by cohesive neoplastic cells that form gland-like tubular structures. The diffuse type is a poorly differentiated tumor in which individual cells infiltrate and thicken the gastric wall. Although the cell of origin in gastric cancer is not yet determined, gastric stem cells are considered a strong candidate because the differentiated daughter cells have a limited lifespan $[6,7]$. Moreover, the self-renewal mechanism of gastric stem cells can be used by gastric cancer stem cells, and their differentiation can be blocked during cancer progression. In this paper, we review the mechanisms underlying the selfrenewal and differentiation of gastric stem cells, as well as how abnormalities in these mechanisms contribute to the development of gastric cancer stem cells.

This is an Open Access article distributed under the terms of the Creative Commons Attribution Non-Commercial License (http://creativecommons.org/licenses/by-nc/3.0/) which permits unrestricted non-commercial use, distribution, and reproduction in any medium, provided the original work is properly cited. 


\section{Gastric Stem Cells}

The stomach is divided into 4 sections: the cardia, fundus, body, and pylorus. The pylorus is subdivided into the pyloric antrum and pyloric canal. Each of these sections has slightly different cells and functions. The gastric epithelium is a simple columnar epithelium that is composed of 2 parts: the gastric pit and gastric gland. The gastric pit is lined by surface mucous cells. The gastric gland is composed of various kinds of cells, including mucous neck cells, parietal cells, chief cells, and enteroendocrine cells [8]. These cells are located within 3 distinct regions of the gastric gland denoted by the isthmus, neck, and base. Parietal cells and chief cells are frequently found in gastric glands of the stomach body. However, enteroendocrine cells and mucous cells are found mainly in the antral glands. Extensive studies showed the sequential generation of these gastric epithelial cells from gastric stem cells (Fig. 1). Surface mucous cells, which contain mucous granules and express mucin 5AC, gastrokine-1, trefoil factor family 1 (Tff1), and forkhead box Q1, are suggested to be generated from prepit cells derived from gastric stem cells [68]. The generation of surface mucous cells, which takes 3 days, is regulated by Indian hedgehog (Ihh) and epidermal growth factor (EGF) $[6,7,9,10]$. Mucous neck cells, which express Tff2, are generated from gastric stem cell-derived preneck cells. Interestingly, chief cells whose half-life is 194 days have been suggested to be derived by transdifferentiation of mucous neck cells, which takes 14 days [6, 7]. The generation and differentiation of chief cells are regulated by the basic helix-loop-helix transcription factor Mist1, and retinoic acid [11-13]. Parietal cells, generated from gastric stem cellderived preparietal cells, secrete acid and express various genes, including Arf1, Sod2, Cdhr5, Fads1, Calm2, Igfbp2, and Pthlh [8]; they are regulated by sonic hedgehog (Shh), gastrin, and bone morphogenetic protein (BMP) [14-16].

Gastric stem cells are assumed to be present in the isthmus region of the gastric gland because cellular proliferation and immature cells were observed in this region. Many previous studies have attempted to find a specific marker for gastric stem cells, the progress of which has been recently reviewed [17]. Although a clear molecular marker for gastric stem cells is not yet defined, most researchers agree on the existence of gastric stem cells [17].

\section{Signaling Pathways for Self-renewal and Differentiation of Gastric Stem Cells}

\section{Hedgehog signaling}

In the adult stomach, parietal cells in the stomach body express the Shh protein and mRNA [18, 19]. Patched 1 (Ptch1),

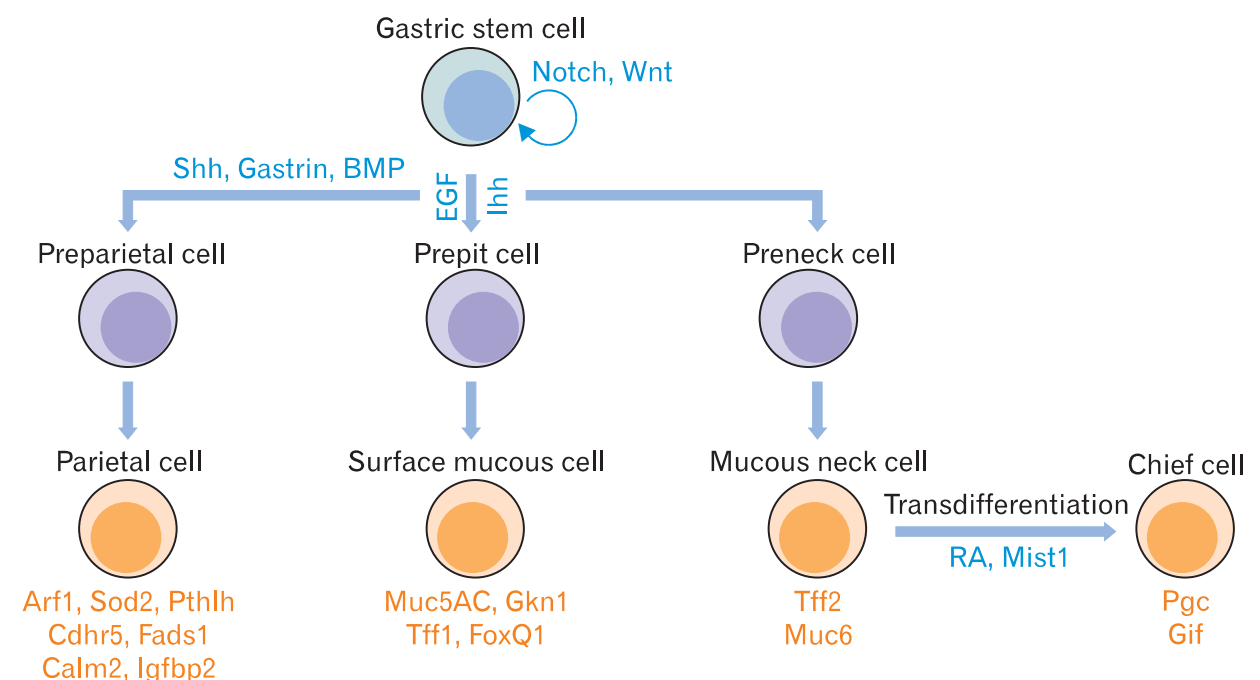

Fig. 1. Self-renewal and differentiation of gastric stem cells. Gastric stem cells have the capacity to self-renew and to differentiate into various kinds of daughter cells, including surface mucous cells, mucous neck cells, chief cells, and parietal cells. Critical signaling pathways for each differentiation route are indicated in blue. Characteristic genes for each of the differentiated cells are indicated in orange. Arf1, ADP-ribosylation factor 1; BMP, bone morphogenetic protein; Calm2, calmodulin 2; Cdhr5, cadherin-related family member5; EGF, epidermal growth factor; Fads1, fatty acid desaturase 1; FoxQ1, forkhead box Q1; Gif, gastric intrinsic factor; Gkn1, gastrokine-1; Ihh, Indian hedgehog; Igfbp2, insulin-like growth factor binding protein 2; Mist1, basic helix-loop-helix transcription factor; Muc5AC, mucin 5AC; Muc6, mucin 6; Notch, Notch signaling pathway; Pgc, pepsinogen C; Pthlh, parathyroid hormone-like hormone; RA, retinoic acid; Shh, sonic hedgehog; Sod2, superoxide dismutase 2; Tff1, trefoil factor family 1; Tff2, trefoil factor family 2; Wnt, Wnt signaling pathway. 
a receptor for hedgehog signaling, is expressed in gastric epithelial cells and mesenchymal cells $[19,20]$. According to this expression pattern, hedgehog signaling regulated the expression of its target genes FoxA2, Isl-1, and $\mathrm{H}^{+} / \mathrm{K}^{+}$ATPase in parietal cells and BMP4 in mesenchymal cells [19]. These findings suggest that hedgehog signaling in the stomach works in both autocrine and paracrine fashions. Ihh is expressed in the surface mucous cells and may contribute to the differentiation and maintenance of this lineage $[9,21]$. Gastrin, histamine, and EGF can increase the expression of Shh $[14,22]$. However, interleukin (IL)- $1 \beta$ and tumor necrosis factor-alpha (TNF- $\alpha$ ) can decrease the expression [23].

Many studies have suggested that hedgehog signaling induces the differentiation of gastric stem cells in the adult stomach. In the isthmus region, which contains proliferating gastric stem cells, Ptch1 was not expressed [9]. Pharmacological inhibition of hedgehog signaling in the mice increased epithelial proliferation by $60-70 \%$ [19]. Shh expression correlated with fundic gland differentiation of the stomach [18]. Treatment of primary parietal cells with Shh ligand increased $\mathrm{H}^{+} / \mathrm{K}^{+}$-ATPase expression [14]. Genetic or pharmacological blocking of hedgehog signaling decreased the differentiation of newly generated epithelial cells but increased their proliferation in the induced-gastric ulcer model $[24,25]$. Hedgehog signaling increased epithelial cell differentiation through the induction of E-cadherin [26]. Finally, the specific knockout of hedgehog signaling in parietal cells decreased the number of mucous neck cells and chief cells [27]. In mice lacking Shh in parietal cells, the phenotypes such as decreased mucous neck cells and chief cells were reversed by treatment with the somatostatin analog, suggesting the effects of hedgehog signaling are indirect [27].

\section{Wnt signaling}

In the adult stomach, the expressions of Wnt ligands and their receptors are poorly characterized, although the expression of Wnt signaling in gastric stem cells has been suggested by the transcript analysis study by using laser capture microdissected gastric stem cells [28]. When Wnt signaling was overexpressed in gastric epithelial cells, gastric epithelial cell dedifferentiation and adenoma formation were observed [29]. In the Apc mutation, which leads to the activation of Wnt signaling, hyperplastic polyps were observed in the antrum of patients [30,31].

\section{Notch signaling}

The expression of hairy and enhancer of split-1 (Hes1), a target gene of Notch signaling, was observed in the isthmus region of gastric glands [32]. Pharmacological inhibition of Notch signaling blocked proliferation in the isthmus region, but its overexpression in parietal cells increased proliferation. Interestingly, Notch-overexpressing parietal cells dedifferentiated into multipotent stem cells, which gave rise to cells of all lineage of the gastric epithelium [32]. These results suggest that Notch signaling is critical for the maintenance of gastric stem cells. Another role of Notch signaling is the inhibition of enteroendocrine cell differentiation, possibly via neurogenin 3 regulation. In mice lacking Hes 1 , the number of enteroendocrine cells was increased [33].

\section{EGF signaling}

EGF signaling is mediated by a typical receptor tyrosine kinase pathway. Seven vertebrate EGF ligands are synthesized as type 1 transmembrane protein, and soluble ligands are released after proteolytic cleavage by membrane protease [34]. In addition to salivary glands, parietal cells secrete several kinds of EGFs, including HB-EGF, amphiregulin, and transforming growth factor-alpha (TGF- $\alpha$ ) [35]. Surface epithelial cells and enteroendocrine cells also secrete TGF- $a$ [36]. Gastrin can increase the expression of these growth factors except TGF- $\alpha$ [37]. Four kinds of EGF receptors (ErbB1, ErbB2, ErbB3, and ErbB4) have been previously described [34]. Although receptors for EGFs are reported to be expressed in the surface epithelial cell layer, subtypes of those receptors in a specific region are poorly characterized. Studies using TGF- $\alpha$-transgenic mice, where foveolar hyperplasia occurs at the expense of parietal and chief cells, have suggested roles of EGF signaling in gastric progenitor cell differentiation [10]. A similar phenomenon was reported in Menetrier's disease, in which EGF signaling is increased $[10,38]$. In waved-2 mice, which harbor a hypomorphic mutation of the EGF receptor, the development of spasmolytic polypeptide-expressing metaplasia (SPEM) was accelerated [39]. Similarly, loss of amphiregulin in parietal cells also showed SPEM, although the loss of TGF- $\alpha$ did not [40]. However, during the course of SPEM in amphiregulin knockout mice, an inflammatory response was observed, which may have been a contributing factor.

\section{BMP signaling}

Receptors and ligands of BMP signaling are expressed in 
both epithelial and mesenchymal cells of the stomach [18, 19, 41-43]. When BMPrla was removed from the endoderm during the early developmental period, the number of parietal cells decreased, whereas the number of enteroendocrine cells increased, suggesting BMP signaling regulates proliferation and commitment of enteroendocrine precursor cells [44]. When Noggin, an antagonist of BMP signaling, was overexpressed in parietal cells, the number of parietal cells decreased and Tff2-expressing cells were expanded [15]. In these mice, the acidity of the gastric fluid was decreased and secretion of gastrin, amphiregulin, and TGF- $\alpha$ was increased. These in vivo data suggest that BMP signaling is required for parietal cell differentiation. In accordance with these data, BMP4 treatment in cultured parietal cells increased the $\mathrm{H}^{+} / \mathrm{K}^{+}$ATPase expression [42].

\section{Gastric Cancer Stem Cell}

\section{Precancerous change}

The intestinal type of gastric cancer develops through a multistep process composed of atrophic gastritis, metaplasia, dysplasia, and cancer. Two types of metaplasia have been reported, including intestinal metaplasia and SPEM [45]. In intestinal metaplasia, the gastric epithelium is transformed into the intestinal epithelium, with the typical pathological finding being the appearance of goblet cells. CDX2 plays a key role in this reprogramming of intestinal dysplasia. When CDX2 was induced in the stomach of mice, intestinal metaplasia was induced $[46,47]$. A recent study showed that CDX1 can reprogram gastric epithelial cells into intestinal epithelial cells through the induction of SALL4 and KLF5 [48]. In SPEM, parietal and chief cells disappear and Tff2expressing cells expand, indicating antralization of the fundic mucosa. A study using Mist1-cre knockin mice showed that chief cells transdifferentiated into Tff2-expressing cells [49]. More studies are needed to determine whether these metaplastic cells are derived directly from gastric stem cells or from transdifferentiation of differentiated cells.
Table 1. Isolation of cancer stem cells from gastric cancer patients*

\begin{tabular}{lllc}
\hline Surface marker & \multicolumn{1}{c}{ Source } & \multicolumn{1}{c}{ Xenograft } & Reference \\
\hline EpCAM/CD44 & Primary gastric cancer & Nude mice & {$[50]$} \\
CD44/CD54 & $\begin{array}{c}\text { Primary gastric cancer/ } \\
\text { peripheral blood }\end{array}$ & Nude/scid mice & {$[51]$} \\
CD90 & Primary gastric cancer & Nude mice & {$[52]$} \\
CD44/CD24 & Primary gastric cancer & NOD/SCID & {$[53]$} \\
\hline
\end{tabular}

NOD, non-obese diabetic; SCID, severe combined immunodeficiency.

*The isolation of cancer stem cells from cell lines was not considered.
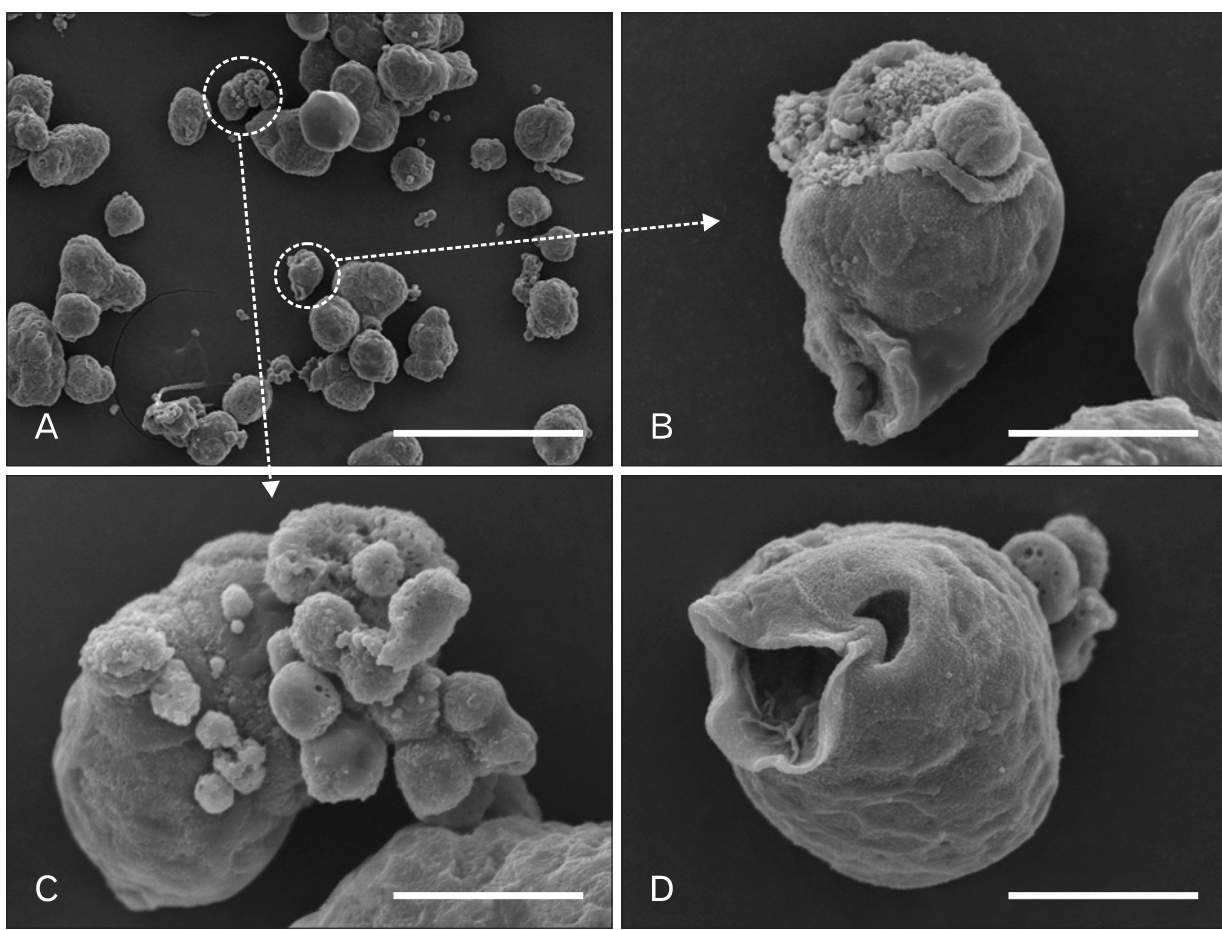

Fig. 2. (A-D) Electron microscope images of gastric cancer stem cells. Seven days after the single-cell culture, images were taken using a scanning electron microscope (Hitachi S3500N). Note the cavities inside the cancer spheres (A, $\times 180 ; \mathrm{B}-\mathrm{D}, \times 1,500)$. Scale bars $=200$ $\mu \mathrm{m}(\mathrm{A}), 30 \mu \mathrm{m}(\mathrm{B}-\mathrm{D})$. 


\section{Isolation of gastric cancer stem cell from patients}

After the demonstration of cancer stem cells in leukemia by John Dick's group, cancer stem cells were successfully isolated from numerous solid cancers, including brain cancer, breast cancer, and pancreatic cancer [2, 3]. Several groups have attempted to isolate cancer stem cells from gastric cancer patients (Table 1). Both EpCAM and CD44 surface markers were used in the first such attempt, in which the xenograft showed a similar heterogenous phenotype of original patients $[50,54]$. Moreover, the single-cell-originated cancer spheres showed various kinds of daughter cells. Interestingly, electron microscopic images of cancer spheres showed various shapes of cavities inside the spheres (Fig. 2), which were also reported by another study [55]. In the subsequent study using CD44 and CD54, gastric cancer stem cells were successfully isolated from the blood of gastric cancer patients [51]. In a recent study, the CD90 marker was used [52]. Interestingly, CD90-positive gastric cancer stem cells overexpressed ErbB2, suggesting that the anti-ErbB2 antibody can be used to eradicate gastric cancer stem cells. The CD44 and CD24 combination has also been used for the isolation attempts [53].

\section{Signaling Pathways for Self-renewal and Differentiation of Gastric Cancer Stem Cells}

\section{Hedgehog signaling}

After long-term inflammation, gastric epithelial cells are transformed into neoplastic cells. During the progression of gastritis, a frequent loss of Shh expression was observed [56]. This disappearance is consistent with that of parietal cells. Moreover, inflammatory cytokines such as IL-1 and TNF- $\alpha$ can reduce Shh expression [23]. The disappearance of Shh may promote the transformational process of gastric epithelial cells because its main role in gastric stem cells is to induce gastric differentiation, as discussed above. However, in more than two-thirds of primary gastric cancers, an enhancement of hedgehog signaling was reported, which was indicated by overexpression of hedgehog target genes Ptch1 and Gli1 $[9,57]$. Overexpression of hedgehog signaling promoted the proliferation and survival of gastric cancer cells and was positively correlated with poorly differentiated and aggressive gastric cancer [20, 58, 59]. Moreover, hedgehog signaling enhanced the metastasis of gastric cancer cells through the activation of TGF- $\beta$ signaling [60]. However, the differences in roles of hedgehog signaling between gastric stem cells and cancer cells are not clear. A recent study showed that
Shh was derived from bone-marrow-derived mesenchymal stem cells that were recruited to the stomach during chronic inflammation [61]. The recruitment and potential role of bone-marrow-derived mesenchymal stem cells in gastric tumorigenesis was reported by Houghton et al. [62].

The roles of hedgehog signaling in cancer stem cells have been described in many cancers, including multiple myeloma, glioblastoma, colon cancer, and pancreatic cancer [63]. A recent study showed that hedgehog signaling is essential for the maintenance of cancer stem cell-like cells in gastric cancer [64]. They found that the overexpression of hedgehog signaling in tumorsphere cells and interruption of hedgehog signaling by cyclopamine or 5E1 antibody reduced the selfrenewing capacity. Another study showed that CD44+CD24+ cells isolated from a gastric cancer cell line had the capacity to self-renew and produce differentiated progeny, and showed increased expression of hedgehog signaling molecules, including Shh, Ptch1, and Gli3, compared with CD44-CD24cells [53].

\section{Wnt signaling}

The importance of the Wnt signaling pathway in selfrenewal of cancer stem cells was reported in colorectal cancer, breast cancer, and myeloid leukemia [65]. It has also been suggested to regulate self-renewal of gastric cancer stemlike cells [66]. In that study, blocking of Wnt signaling by the Dickkopf homolog 1 protein caused a reduction in the selfrenewing capacity of MKN45 tumorsphere cells. Moreover, nuclear localization of $\beta$-catenin, indicating activation of Wnt signaling, was found in approximately $30 \%$ of gastric cancers $[67,68]$. Mutation or loss of heterozygosity in the Apc gene was found in $18 \%$ or $21 \%$ of gastric cancers, respectively [69]. Although the incidence is variable depending on research group, $\beta$-catenin mutation was detected in gastric cancer $[68,70,71]$. Animal studies also support that Wnt signaling increases gastric cancer development. K19-Wnt1 transgenic mice expressing Wnt1 in the gastric mucosa, using the keratin 19 promoter, showed a significant suppression of epithelial differentiation with small preneoplastic lesions [72]. When these mice were crossed with K19-C2mE transgenic mice expressing cyclooxygenase-2 (Cox-2) and microsomal prostaglandin E synthase-1 (mPGES-1) in the stomach, mucous cell metaplasia and dysplastic gastric tumors were observed.

\section{Notch signaling}

Notch signaling is implicated in the self-renewal of various 
cancer stem cells, including breast cancer, medulloblastoma, and pancreatic cancer [73]. Although there is no direct evidence supporting the roles of Notch signaling in gastric cancer stem cells, abnormal activation of Notch signaling was observed in gastric cancer. Approximately $75 \%$ of primary gastric cancers expressed the Notch ligand Jag1, with the expression status correlating with cancer aggressiveness and patient survival rate [74]. Interestingly, Notch signaling promoted colony formation, migration, and invasion of gastric cancer cells partially through Cox-2 [74]. Another study showed that Notch signaling promoted gastric cancer progression through Twist expression and phosphorylation of the signal transducer and activator of transcription 3 [75].

\section{EGF signaling}

Roles of EGF signaling in cancer stem cells were suggested in breast cancer [76] and glioblastoma [77]. Although the roles were not examined in gastric cancer stem cells, abnormal activation of EGF signaling has been reported, where amplification of ErbB2 was observed in up to $27 \%$ of gastric cancers [78]. K-ras mutation was detected in the intestinal type of gastric cancer $[79,80]$. EGF receptor overexpression is associated with a poor prognosis in gastric cancer $[81,82]$.

\section{TGF- $\beta$ and BMP signaling}

Previous studies showed TGF- $\beta$ signaling has dual roles in cancer progression $[83,84]$. In the early stages of cancer, TGF- $\beta$ signaling acts as a tumor suppressor by inhibiting cellular proliferation or by promoting cellular differentiation and apoptosis. However, in the later stages, TGF- $\beta$ signaling enhances cancer cells invasion and metastasis. Runx3, a target gene of TGF- $\beta$ signaling, can suppress the progression of gastric cancer by inducing claudin-1 [85]. Moreover, Runx3 works as an antagonist for Wnt signaling, which is a critical signaling pathway for maintenance of stem cells, and antagonizes the epithelial-mesenchymal-transition of gastric epithelial cells [86]. Helicobacter pylori can methylate the promoter and induce loss of Runx3 in gastric epithelial cells [87].

BMP signaling in the stomach is up-regulated during inflammation and down-regulated during cancer progression $[67,88]$. BMP signaling activity was mostly detected in the differentiated surface cells and gland cells in healthy mucosa [88]. In gastric cancer tissues, the expression of BMP2 was epigenetically down-regulated [89]. Moreover, BMP2 and BMP4 suppressed gastric cancer cell proliferation [90, 91].
However, other studies showed that BMP2 promoted gastric cancer cell migration and invasion, and its overexpression positively correlated with the tumor progression and metastasis [92-95]. Although the role of BMP signaling were not examined in gastric cancer stem cells, its roles were suggested in breast cancer [96] and prostate cancer [97].

\section{Nuclear factor $\kappa$-light-chain-enhancer of activated B cells $(\mathrm{NF}-\kappa \mathrm{B})$ signaling}

Most gastric cancers evolve from chronic gastritis. Therefore, major signaling pathways that are critical for chronic inflammation affect cancer progression. One of those inflammatory signaling pathways is NF- $\kappa \mathrm{B}$, a family of bipartite transcription factors that include NF- $\kappa \mathrm{B} 1, \mathrm{NF}-\kappa \mathrm{B} 2, \mathrm{c}-\mathrm{Rel}$, RelA, and RelB [98]. The dimerized transcription factors are normally bound by $\mathrm{I} \kappa \mathrm{B}$, an inhibitor of NF- $\kappa \mathrm{B}$, and thereby restricted to the cytoplasm. When inflammatory cytokines or bacterial components activate the cells, I $\mathrm{B}$ is phosphorylated by an I $\kappa B$ kinase complex and subject to proteasomal degradation, which releases NF- $\kappa \mathrm{B}$ that translocates into the nucleus and activates the target genes [98].

NF- $\kappa \mathrm{B}$ activity in self-renewal of cancer stem cells have been reported in breast cancer [99], prostate cancer [100], and glioblastoma [101]. A number of cytokines, including IL-6 and IL-8, can activate NF- $\kappa B$, and a positive feedback loop between the expression of cytokines and the activity of $\mathrm{NF}-\kappa \mathrm{B}$ can be formed to maintain a chronic inflammatory state [102]. Although there is no direct evidence for the roles of NF- $\kappa B$ signaling in gastric cancer stem cells, aberrant activation of NF- $\mathrm{KB}$ in gastric cancer contributes to increased proliferation, evasion of apoptosis, genomic instability, and drug resistance $[67,103,104]$. Moreover, H. pylori induces various inflammatory cytokines through activation of the NF$\kappa \mathrm{B}$ pathway $[67,105-107]$.

\section{Cox-2}

Cox-2 is a critical enzyme for the conversion of arachidonic acid to prostaglandins (PGs), among which prostaglandin E2 (PGE2) plays a key role in the Cox-2-induced promotion of gastric cancer [108]. H. pylori infection can induce the expression of Cox-2 and mPGES-1 in the gastric mucosa [109]. Cox-2 and PG can induce angiogenesis and heavy infiltration of macrophages $[110,111]$. Although there is no direct evidence that Cox-2 and PG contribute to self-renewal of gastric cancer stem cells, there is a possibility that these molecules reconstruct the inflammatory microenvironment 
of cancer stem cells, which finally affects their self-renewal. A recent study in colorectal cancer cells showed that PGE2 released from mesenchymal stem cells enhanced the formation of cancer stem cells and other cytokines [112]. The additional expression of Cox-2 and mPGES-1 converted the preneoplastic lesions into dysplastic tumors in mice overexpressing Wnt1 in gastric epithelial cells [72].

\section{Conclusion and Future Directions}

Despite many laboratory efforts, there is no highly specific marker for gastric stem cells. This slows down any attempt to elucidate the regulatory mechanisms underlying the selfrenewal and differentiation of gastric stem cells. Moreover, the chronic inflammatory process can change the characteristics and regulatory mechanisms of gastric stem cells, which makes it more difficult to determine the origin of gastric cancer. A better understanding about the regulatory mechanisms of gastric stem cells can be applied to develop therapeutics for not only gastric cancer but also gastric ulcer. To achieve these goals, the identification of a specific marker is imperative.

In addition, the importance of the microenvironment for cancer stem cells cannot be underestimated. For example, hepatocyte growth factor secreted by cancer-associated fibroblasts increased the self-renewal of colon cancer stem cells through activation of the Wnt signaling pathway [113]. Notably, chronic gastritis can recruit bone marrow-derived mesenchymal stem cells, and they differentiate into cancerassociated fibroblasts that sustain cancer progression in a TGF- $\beta$ and stroma-derived factor- $1 \alpha$-dependent manner [54, 61]. Moreover, many inflammatory cells, including macrophages, can affect the self-renewal of cancer stem cells [102]. Thus, the interactions between inflammatory cells and gastric cancer stem cells need to be examined because most gastric cancers evolve from chronic gastritis.

One of the critical problems in the treatment for cancer is the heterogeneity of cancer cells, rendering treatment for a specific target unpromising. The heterogeneity of cancer cells can be explained by the different origins of cancer cells and cancer stem cells. Although cancer stem cells generate various kinds of daughter cells and contribute to the heterogeneity, cancer stem cells themselves are genetically evolving. Therefore, the evolutionary process of cancer stem cells also needs to be examined for the development of new therapeutic drugs for gastric cancer.

\section{Acknowledgements}

This work was supported for 2 years by the Pusan National University Research Grant.

\section{References}

1. Clarke MF, Dick JE, Dirks PB, Eaves CJ, Jamieson CH, Jones DL, Visvader J, Weissman IL, Wahl GM. Cancer stem cells: perspectives on current status and future directions: AACR Workshop on cancer stem cells. Cancer Res 2006;66:9339-44.

2. Huntly BJ, Gilliland DG. Leukaemia stem cells and the evolution of cancer-stem-cell research. Nat Rev Cancer 2005;5:311-21.

3. Visvader JE, Lindeman GJ. Cancer stem cells in solid tumours: accumulating evidence and unresolved questions. Nat Rev Cancer 2008;8:755-68.

4. Yuasa Y. Control of gut differentiation and intestinal-type gastric carcinogenesis. Nat Rev Cancer 2003;3:592-600.

5. Gill S, Shah A, Le N, Cook EF, Yoshida EM. Asian ethnicityrelated differences in gastric cancer presentation and outcome among patients treated at a canadian cancer center. J Clin Oncol 2003;21:2070-6

6. Karam SM, Leblond CP. Dynamics of epithelial cells in the corpus of the mouse stomach. III. Inward migration of neck cells followed by progressive transformation into zymogenic cells. Anat Rec 1993;236:297-313.

7. Karam SM, Leblond CP. Dynamics of epithelial cells in the corpus of the mouse stomach. II. Outward migration of pit cells. Anat Rec 1993;236:280-96.

8. Khurana S, Mills JC. The gastric mucosa development and differentiation. Prog Mol Biol Transl Sci 2010;96:93-115.

9. Fukaya M, Isohata N, Ohta H, Aoyagi K, Ochiya T, Saeki N, Yanagihara K, Nakanishi Y, Taniguchi H, Sakamoto H, Shimoda T, Nimura Y, Yoshida T, Sasaki H. Hedgehog signal activation in gastric pit cell and in diffuse-type gastric cancer. Gastroenterology 2006;131:14-29.

10. Nomura S, Settle SH, Leys CM, Means AL, Peek RM Jr, Leach SD, Wright CV, Coffey RJ, Goldenring JR. Evidence for repatterning of the gastric fundic epithelium associated with Menetrier's disease and TGFalpha overexpression. Gastroenterology 2005;128:1292-305.

11. Ramsey VG, Doherty JM, Chen CC, Stappenbeck TS, Konieczny SF, Mills JC. The maturation of mucus-secreting gastric epithelial progenitors into digestive-enzyme secreting zymogenic cells requires Mist1. Development 2007;134:211-22.

12. Tian X, Jin RU, Bredemeyer AJ, Oates EJ, Blazewska KM, McKenna CE, Mills JC. RAB26 and RAB3D are direct transcriptional targets of MIST1 that regulate exocrine granule maturation. Mol Cell Biol 2010;30:1269-84.

13. Karam SM, John R, Alpers DH, Ponery AS. Retinoic acid stimulates the dynamics of mouse gastric epithelial progenitors. Stem Cells 2005;23:433-41. 
14. Stepan V, Ramamoorthy S, Nitsche H, Zavros Y, Merchant JL, Todisco A. Regulation and function of the sonic hedgehog signal transduction pathway in isolated gastric parietal cells. J Biol Chem 2005;280:15700-8.

15. Shinohara M, Mao M, Keeley TM, El-Zaatari M, Lee HJ, Eaton KA, Samuelson LC, Merchant JL, Goldenring JR, Todisco A. Bone morphogenetic protein signaling regulates gastric epithelial cell development and proliferation in mice. Gastroenterology 2010;139:2050-60.e2.

16. Wang TC, Koh TJ, Varro A, Cahill RJ, Dangler CA, Fox JG, Dockray GJ. Processing and proliferative effects of human progastrin in transgenic mice. J Clin Invest 1996;98:1918-29.

17. Qiao XT, Gumucio DL. Current molecular markers for gastric progenitor cells and gastric cancer stem cells. J Gastroenterol 2011;46:855-65.

18. van den Brink GR, Hardwick JC, Nielsen C, Xu C, ten Kate FJ, Glickman J, van Deventer SJ, Roberts DJ, Peppelenbosch MP. Sonic hedgehog expression correlates with fundic gland differentiation in the adult gastrointestinal tract. Gut 2002;51:628-33.

19. van den Brink GR, Hardwick JC, Tytgat GN, Brink MA, Ten Kate FJ, Van Deventer SJ, Peppelenbosch MP. Sonic hedgehog regulates gastric gland morphogenesis in man and mouse. Gastroenterology 2001;121:317-28.

20. Berman DM, Karhadkar SS, Maitra A, Montes De Oca R, Gerstenblith MR, Briggs K, Parker AR, Shimada Y, Eshleman JR, Watkins DN, Beachy PA. Widespread requirement for Hedgehog ligand stimulation in growth of digestive tract tumours. Nature 2003;425:846-51.

21. van den Brink GR. Hedgehog signaling in development and homeostasis of the gastrointestinal tract. Physiol Rev 2007;87:1343-75.

22. Zavros Y, Waghray M, Tessier A, Bai L, Todisco A, Gumucio DL, Samuelson LC, Dlugosz A, Merchant JL. Reduced pepsin A processing of sonic hedgehog in parietal cells precedes gastric atrophy and transformation. J Biol Chem 2007;282:33265-74.

23. Waghray M, Zavros Y, Saqui-Salces M, El-Zaatari M, Alamelumangapuram CB, Todisco A, Eaton KA, Merchant JL. Interleukin-1beta promotes gastric atrophy through suppression of Sonic Hedgehog. Gastroenterology 2010;138:562-72, 572.e1-2.

24. Kang DH, Han ME, Song MH, Lee YS, Kim EH, Kim HJ, Kim GH, Kim DH, Yoon S, Baek SY, Kim BS, Kim JB, Oh SO. The role of hedgehog signaling during gastric regeneration. J Gastroenterol 2009;44:372-9.

25. Xiao C, Feng R, Engevik AC, Martin JR, Tritschler JA, Schumacher M, Koncar R, Roland J, Nam KT, Goldenring JR, Zavros Y. Sonic Hedgehog contributes to gastric mucosal restitution after injury. Lab Invest 2013;93:96-111.

26. Xiao C, Ogle SA, Schumacher MA, Schilling N, Tokhunts RA, Orr-Asman MA, Miller ML, Robbins DJ, Hollande F, Zavros Y. Hedgehog signaling regulates E-cadherin expression for the maintenance of the actin cytoskeleton and tight junctions. Am J Physiol Gastrointest Liver Physiol 2010;299:G1252-65.

27. Xiao C, Ogle SA, Schumacher MA, Orr-Asman MA, Miller ML,
Lertkowit N, Varro A, Hollande F, Zavros Y. Loss of parietal cell expression of Sonic hedgehog induces hypergastrinemia and hyperproliferation of surface mucous cells. Gastroenterology 2010;138:550-61, 561.e1-8.

28. Giannakis M, Stappenbeck TS, Mills JC, Leip DG, Lovett M, Clifton SW, Ippolito JE, Glasscock JI, Arumugam M, Brent MR, Gordon JI. Molecular properties of adult mouse gastric and intestinal epithelial progenitors in their niches. J Biol Chem 2006;281:11292-300.

29. Radulescu S, Ridgway RA, Cordero J, Athineos D, Salgueiro P, Poulsom R, Neumann J, Jung A, Patel S, Woodgett J, Barker N, Pritchard DM, Oien K, Sansom OJ. Acute WNT signalling activation perturbs differentiation within the adult stomach and rapidly leads to tumour formation. Oncogene 2012 Jun 4 [Epub] http://dx.doi.org/10.1038/onc.2012.224.

30. Watanabe H, Enjoji M, Yao T, Ohsato K. Gastric lesions in familial adenomatosis coli: their incidence and histologic analysis. Hum Pathol 1978;9:269-83.

31. Bianchi LK, Burke CA, Bennett AE, Lopez R, Hasson H, Church JM. Fundic gland polyp dysplasia is common in familial adenomatous polyposis. Clin Gastroenterol Hepatol 2008;6:1805.

32. Kim TH, Shivdasani RA. Notch signaling in stomach epithelial stem cell homeostasis. J Exp Med 2011;208:677-88.

33. Jensen J, Pedersen EE, Galante P, Hald J, Heller RS, Ishibashi M, Kageyama R, Guillemot F, Serup P, Madsen OD. Control of endodermal endocrine development by Hes-1. Nat Genet 2000;24:36-44.

34. Fiske WH, Threadgill D, Coffey RJ. ERBBs in the gastrointestinal tract: recent progress and new perspectives. Exp Cell Res 2009;315:583-601.

35. Hoffmann W. Stem cells, self-renewal and cancer of the gastric epithelium. Curr Med Chem 2012;19:5975-83.

36. Tang LH, Modlin IM, Lawton GP, Kidd M, Chinery R. The role of transforming growth factor alpha in the enterochromaffinlike cell tumor autonomy in an African rodent mastomys. Gastroenterology 1996;111:1212-23.

37. Tsutsui S, Shinomura Y, Higashiyama S, Higashimoto Y, Miyazaki Y, Kanayama S, Hiraoka S, Minami T, Kitamura S, Murayama Y, Miyagawa J, Taniguchi N, Matsuzawa Y. Induction of heparin binding epidermal growth factor-like growth factor and amphiregulin mRNAs by gastrin in the rat stomach. Biochem Biophys Res Commun 1997;235:520-3.

38. Coffey RJ, Washington MK, Corless CL, Heinrich MC. Ménétrier disease and gastrointestinal stromal tumors: hyperproliferative disorders of the stomach. J Clin Invest 2007;117:70-80.

39. Ogawa M, Nomura S, Varro A, Wang TC, Goldenring JR. Altered metaplastic response of waved-2 EGF receptor mutant mice to acute oxyntic atrophy. Am J Physiol Gastrointest Liver Physiol 2006;290:G793-804.

40. Nam KT, Varro A, Coffey RJ, Goldenring JR. Potentiation of oxyntic atrophy-induced gastric metaplasia in amphiregulindeficient mice. Gastroenterology 2007;132:1804-19.

41. Danesh SM, Villasenor A, Chong D, Soukup C, Cleaver O. BMP 
and BMP receptor expression during murine organogenesis. Gene Expr Patterns 2009;9:255-65.

42. Nitsche H, Ramamoorthy S, Sareban M, Pausawasdi N, Todisco A. Functional role of bone morphogenetic protein-4 in isolated canine parietal cells. Am J Physiol Gastrointest Liver Physiol 2007;293:G607-14.

43. Bleuming SA, He XC, Kodach LL, Hardwick JC, Koopman FA, Ten Kate FJ, van Deventer SJ, Hommes DW, Peppelenbosch MP, Offerhaus GJ, Li L, van den Brink GR. Bone morphogenetic protein signaling suppresses tumorigenesis at gastric epithelial transition zones in mice. Cancer Res 2007;67:8149-55.

44. Maloum F, Allaire JM, Gagné-Sansfaçon J, Roy E, Belleville K, Sarret P, Morisset J, Carrier JC, Mishina Y, Kaestner KH, Perreault N. Epithelial BMP signaling is required for proper specification of epithelial cell lineages and gastric endocrine cells. Am J Physiol Gastrointest Liver Physiol 2011;300:G106579.

45. Mills JC, Shivdasani RA. Gastric epithelial stem cells. Gastroenterology 2011;140:412-24.

46. Mutoh H, Hakamata Y, Sato K, Eda A, Yanaka I, Honda S, Osawa H, Kaneko Y, Sugano K. Conversion of gastric mucosa to intestinal metaplasia in $\mathrm{Cdx} 2$-expressing transgenic mice. Biochem Biophys Res Commun 2002;294:470-9.

47. Silberg DG, Sullivan J, Kang E, Swain GP, Moffett J, Sund NJ, Sackett SD, Kaestner KH. Cdx2 ectopic expression induces gastric intestinal metaplasia in transgenic mice. Gastroenterology 2002;122:689-96.

48. Fujii Y, Yoshihashi K, Suzuki H, Tsutsumi S, Mutoh H, Maeda S, Yamagata Y, Seto Y, Aburatani H, Hatakeyama M. CDX1 confers intestinal phenotype on gastric epithelial cells via induction of stemness-associated reprogramming factors SALL4 and KLF5. Proc Natl Acad Sci U S A 2012;109:20584-9.

49. Nam KT, Lee HJ, Sousa JF, Weis VG, O'Neal RL, Finke PE, Romero-Gallo J, Shi G, Mills JC, Peek RM Jr, Konieczny SF, Goldenring JR. Mature chief cells are cryptic progenitors for metaplasia in the stomach. Gastroenterology 2010;139:2028-37. e9.

50. Han ME, Jeon TY, Hwang SH, Lee YS, Kim HJ, Shim HE, Yoon S, Baek SY, Kim BS, Kang CD, Oh SO. Cancer spheres from gastric cancer patients provide an ideal model system for cancer stem cell research. Cell Mol Life Sci 2011;68:3589-605.

51. Chen T, Yang K, Yu J, Meng W, Yuan D, Bi F, Liu F, Liu J, Dai B, Chen X, Wang F, Zeng F, Xu H, Hu J, Mo X. Identification and expansion of cancer stem cells in tumor tissues and peripheral blood derived from gastric adenocarcinoma patients. Cell Res 2012;22:248-58

52. Jiang J, Zhang Y, Chuai S, Wang Z, Zheng D, Xu F, Zhang Y, Li C, Liang Y, Chen Z. Trastuzumab (herceptin) targets gastric cancer stem cells characterized by CD90 phenotype. Oncogene 2012;31:671-82.

53. Zhang C, Li C, He F, Cai Y, Yang H. Identification of CD44+ CD24+ gastric cancer stem cells. J Cancer Res Clin Oncol 2011;137:1679-86.

54. Xu G, Shen J, Ou Yang X, Sasahara M, Su X. Cancer stem cells: the 'heartbeat' of gastric cancer. J Gastroenterol 2012 Nov 27 [Epub]. Http://dx.doi.org/10.1007/s00535-012-0712-y.

55. Su YJ, Lai HM, Chang YW, Chen GY, Lee JL. Direct reprogramming of stem cell properties in colon cancer cells by CD44. EMBO J 2011;30:3186-99.

56. Martin J, Donnelly JM, Houghton J, Zavros Y. The role of sonic hedgehog reemergence during gastric cancer. Dig Dis Sci 2010; 55:1516-24.

57. Wang LH, Choi YL, Hua XY, Shin YK, Song YJ, Youn SJ, Yun HY, Park SM, Kim WJ, Kim HJ, Choi JS, Kim SH. Increased expression of sonic hedgehog and altered methylation of its promoter region in gastric cancer and its related lesions. Mod Pathol 2006;19:675-83.

58. Han ME, Lee YS, Baek SY, Kim BS, Kim JB, Oh SO. Hedgehog signaling regulates the survival of gastric cancer cells by regulating the expression of Bcl-2. Int J Mol Sci 2009;10:3033-43.

59. Lee SY, Han HS, Lee KY, Hwang TS, Kim JH, Sung IK, Park HS, Jin CJ, Choi KW. Sonic hedgehog expression in gastric cancer and gastric adenoma. Oncol Rep 2007;17:1051-5.

60. Yoo YA, Kang MH, Kim JS, Oh SC. Sonic hedgehog signaling promotes motility and invasiveness of gastric cancer cells through TGF-beta-mediated activation of the ALK5-Smad 3 pathway. Carcinogenesis 2008;29:480-90.

61. Quante M, Tu SP, Tomita H, Gonda T, Wang SS, Takashi S, Baik GH, Shibata W, Diprete B, Betz KS, Friedman R, Varro A, Tycko B, Wang TC. Bone marrow-derived myofibroblasts contribute to the mesenchymal stem cell niche and promote tumor growth. Cancer Cell 2011;19:257-72.

62. Houghton J, Stoicov C, Nomura S, Rogers AB, Carlson J, Li H, Cai X, Fox JG, Goldenring JR, Wang TC. Gastric cancer originating from bone marrow-derived cells. Science 2004; 306:1568-71.

63. Merchant AA, Matsui W. Targeting Hedgehog: a cancer stem cell pathway. Clin Cancer Res 2010;16:3130-40.

64. Song Z, Yue W, Wei B, Wang N, Li T, Guan L, Shi S, Zeng Q, Pei $\mathrm{X}$, Chen $\mathrm{L}$. Sonic hedgehog pathway is essential for maintenance of cancer stem-like cells in human gastric cancer. PLoS One 2011;6:e17687.

65. Takahashi-Yanaga F, Kahn M. Targeting Wnt signaling: can we safely eradicate cancer stem cells? Clin Cancer Res 2010;16:315362.

66. Cai $\mathrm{C}, \mathrm{Zhu} \mathrm{X}$. The Wnt/beta-catenin pathway regulates selfrenewal of cancer stem-like cells in human gastric cancer. Mol Med Rep 2012;5:1191-6.

67. Wu WK, Cho CH, Lee CW, Fan D, Wu K, Yu J, Sung JJ. Dysregulation of cellular signaling in gastric cancer. Cancer Lett 2010; 295:144-53.

68. Clements WM, Wang J, Sarnaik A, Kim OJ, MacDonald J, Fenoglio-Preiser C, Groden J, Lowy AM. Beta-catenin mutation is a frequent cause of Wnt pathway activation in gastric cancer. Cancer Res 2002;62:3503-6.

69. Tahara E. Molecular biology of gastric cancer. World J Surg 1995;19:484-8.

70. Kim B, Byun SJ, Kim YA, Kim JE, Lee BL, Kim WH, Chang 
MS. Cell cycle regulators, APC/beta-catenin, NF-kappaB and Epstein-Barr virus in gastric carcinomas. Pathology 2010;42:5865.

71. Ebert MP, Fei G, Kahmann S, Müller O, Yu J, Sung JJ, Malfertheiner P. Increased beta-catenin mRNA levels and mutational alterations of the APC and beta-catenin gene are present in intestinal-type gastric cancer. Carcinogenesis 2002; 23:87-91.

72. Oshima H, Matsunaga A, Fujimura T, Tsukamoto T, Taketo MM, Oshima M. Carcinogenesis in mouse stomach by simultaneous activation of the Wnt signaling and prostaglandin E2 pathway. Gastroenterology 2006;131:1086-95.

73. Pannuti A, Foreman K, Rizzo P, Osipo C, Golde T, Osborne B, Miele L. Targeting Notch to target cancer stem cells. Clin Cancer Res 2010;16:3141-52.

74. Yeh TS, Wu CW, Hsu KW, Liao WJ, Yang MC, Li AF, Wang AM, Kuo ML, Chi CW. The activated Notch1 signal pathway is associated with gastric cancer progression through cyclooxygenase-2. Cancer Res 2009;69:5039-48.

75. Hsu KW, Hsieh RH, Huang KH, Fen-Yau Li A, Chi CW, Wang TY, Tseng MJ, Wu KJ, Yeh TS. Activation of the Notch1/STAT3/ Twist signaling axis promotes gastric cancer progression. Carcinogenesis 2012;33:1459-67.

76. Hardt O, Wild S, Oerlecke I, Hofmann K, Luo S, Wiencek Y, Kantelhardt E, Vess C, Smith GP, Schroth GP, Bosio A, Dittmer J. Highly sensitive profiling of CD44+/CD24- breast cancer stem cells by combining global mRNA amplification and next generation sequencing: evidence for a hyperactive PI3K pathway. Cancer Lett 2012;325:165-74.

77. Howard BM, Gursel DB, Bleau AM, Beyene RT, Holland EC, Boockvar JA. EGFR signaling is differentially activated in patient-derived glioblastoma stem cells. J Exp Ther Oncol 2010;8:247-60.

78. Gravalos C, Jimeno A. HER2 in gastric cancer: a new prognostic factor and a novel therapeutic target. Ann Oncol 2008;19:15239.

79. Miki H, Ohmori M, Perantoni AO, Enomoto T. K-ras activation in gastric epithelial tumors in Japanese. Cancer Lett 1991;58:10713.

80. Gong C, Mera R, Bravo JC, Ruiz B, Diaz-Escamilla R, Fontham ET, Correa P, Hunt JD. KRAS mutations predict progression of preneoplastic gastric lesions. Cancer Epidemiol Biomarkers Prev 1999;8:167-71.

81. Yoshida K, Tsuda T, Matsumura T, Tsujino T, Hattori T, Ito H, Tahara E. Amplification of epidermal growth factor receptor (EGFR) gene and oncogenes in human gastric carcinomas. Virchows Arch B Cell Pathol Incl Mol Pathol 1989;57:285-90.

82. Matsubara J, Yamada Y, Hirashima Y, Takahari D, Okita NT, Kato K, Hamaguchi T, Shirao K, Shimada Y, Shimoda T. Impact of insulin-like growth factor type 1 receptor, epidermal growth factor receptor, and HER2 expressions on outcomes of patients with gastric cancer. Clin Cancer Res 2008;14:3022-9.

83. Mishra L, Derynck R, Mishra B. Transforming growth factorbeta signaling in stem cells and cancer. Science 2005;310:68-71.

84. Miyazono K, Suzuki H, Imamura T. Regulation of TGF-beta signaling and its roles in progression of tumors. Cancer Sci 2003; 94:230-4.

85. Chang TL, Ito K, Ko TK, Liu Q, Salto-Tellez M, Yeoh KG, Fukamachi H, Ito Y. Claudin-1 has tumor suppressive activity and is a direct target of RUNX3 in gastric epithelial cells. Gastroenterology 2010;138:255-65.e1-3.

86. Voon DC, Wang H, Koo JK, Nguyen TA, Hor YT, Chu YS, Ito K, Fukamachi H, Chan SL, Thiery JP, Ito Y. Runx3 protects gastric epithelial cells against epithelial-mesenchymal transitioninduced cellular plasticity and tumorigenicity. Stem Cells 2012;30:2088-99.

87. Katayama Y, Takahashi M, Kuwayama H. Helicobacter pylori causes runx 3 gene methylation and its loss of expression in gastric epithelial cells, which is mediated by nitric oxide produced by macrophages. Biochem Biophys Res Commun 2009;388:496-500.

88. Bleuming SA, Kodach LL, Garcia Leon MJ, Richel DJ, Peppelenbosch MP, Reitsma PH, Hardwick JC, van den Brink GR. Altered bone morphogenetic protein signalling in the Helicobacter pylori-infected stomach. J Pathol 2006;209:190-7.

89. Wen XZ, Akiyama Y, Baylin SB, Yuasa Y. Frequent epigenetic silencing of the bone morphogenetic protein 2 gene through methylation in gastric carcinomas. Oncogene 2006;25:2666-73.

90. Wen XZ, Miyake S, Akiyama Y, Yuasa Y. BMP-2 modulates the proliferation and differentiation of normal and cancerous gastric cells. Biochem Biophys Res Commun 2004;316:100-6.

91. Shirai YT, Ehata S, Yashiro M, Yanagihara K, Hirakawa K, Miyazono K. Bone morphogenetic protein-2 and -4 play tumor suppressive roles in human diffuse-type gastric carcinoma. Am J Pathol 2011;179:2920-30.

92. Park Y, Kim JW, Kim DS, Kim EB, Park SJ, Park JY, Choi WS, Song JG, Seo HY, Oh SC, Kim BS, Park JJ, Kim YH, Kim JS. The bone morphogenesis protein-2 (BMP-2) is associated with progression to metastatic disease in gastric cancer. Cancer Res Treat 2008;40:127-32.

93. Park Y, Kang MH, Seo HY, Park JM, Choi CW, Kim YH, Kim IS, Kim JS, Oh SC. Bone morphogenetic protein-2 levels are elevated in the patients with gastric cancer and correlate with disease progression. Med Oncol 2010;27:1192-9.

94. Kang MH, Kim JS, Seo JE, Oh SC, Yoo YA. BMP2 accelerates the motility and invasiveness of gastric cancer cells via activation of the phosphatidylinositol 3-kinase (PI3K)/Akt pathway. Exp Cell Res 2010;316:24-37.

95. Kang MH, Oh SC, Lee HJ, Kang HN, Kim JL, Kim JS, Yoo YA. Metastatic function of BMP-2 in gastric cancer cells: the role of PI3K/AKT, MAPK, the NF-kappaB pathway, and MMP-9 expression. Exp Cell Res 2011;317:1746-62.

96. Buijs JT, van der Horst G, van den Hoogen C, Cheung H, de Rooij B, Kroon J, Petersen M, van Overveld PG, Pelger RC, van der Pluijm G. The BMP2/7 heterodimer inhibits the human breast cancer stem cell subpopulation and bone metastases formation. Oncogene 2012;31:2164-74.

97. Kobayashi A, Okuda H, Xing F, Pandey PR, Watabe M, Hirota S, Pai SK, Liu W, Fukuda K, Chambers C, Wilber A, 
Watabe K. Bone morphogenetic protein 7 in dormancy and metastasis of prostate cancer stem-like cells in bone. J Exp Med 2011;208:2641-55

98. Spehlmann ME, Eckmann L. Nuclear factor-kappa B in intestinal protection and destruction. Curr Opin Gastroenterol 2009; 25:92-9.

99. Hinohara K, Kobayashi S, Kanauchi H, Shimizu S, Nishioka K, Tsuji E, Tada K, Umezawa K, Mori M, Ogawa T, Inoue J, Tojo A, Gotoh N. ErbB receptor tyrosine kinase/NF-kappaB signaling controls mammosphere formation in human breast cancer. Proc Natl Acad Sci U S A 2012;109:6584-9.

100. Mimeault M, Johansson SL, Batra SK. Pathobiological implications of the expression of EGFR, pAkt, NF-kappaB and MIC-1 in prostate cancer stem cells and their progenies. PLoS One 2012;7:e31919.

101. Nogueira L, Ruiz-Ontañon P, Vazquez-Barquero A, Lafarga M, Berciano MT, Aldaz B, Grande L, Casafont I, Segura V, Robles EF, Suarez D, Garcia LF, Martinez-Climent JA, Fernandez-Luna JL. Blockade of the NFkappaB pathway drives differentiating glioblastoma-initiating cells into senescence both in vitro and in vivo. Oncogene 2011;30:3537-48.

102. Korkaya H, Liu S, Wicha MS. Regulation of cancer stem cells by cytokine networks: attacking cancer's inflammatory roots. Clin Cancer Res 2011;17:6125-9.

103. Kang MJ, Ryu BK, Lee MG, Han J, Lee JH, Ha TK, Byun DS, Chae KS, Lee BH, Chun HS, Lee KY, Kim HJ, Chi SG. NFkappaB activates transcription of the RNA-binding factor $\mathrm{HuR}$, via PI3K-AKT signaling, to promote gastric tumorigenesis. Gastroenterology 2008;135:2030-42, 42.e1-3.

104. Liu CA, Wang MJ, Chi CW, Wu CW, Chen JY. Rho/Rhotekinmediated NF-kappaB activation confers resistance to apoptosis. Oncogene 2004;23:8731-42.

105. Aihara M, Tsuchimoto D, Takizawa H, Azuma A, Wakebe H, Ohmoto Y, Imagawa K, Kikuchi M, Mukaida N, Matsushima K. Mechanisms involved in Helicobacter pylori-induced interleukin-8 production by a gastric cancer cell line, MKN45. Infect Immun 1997;65:3218-24.

106. Sharma SA, Tummuru MK, Blaser MJ, Kerr LD. Activation of $I L-8$ gene expression by Helicobacter pylori is regulated by transcription factor nuclear factor-kappa B in gastric epithelial cells. J Immunol 1998;160:2401-7.

107. Munzenmaier A, Lange C, Glocker E, Covacci A, Moran A, Bereswill S, Baeuerle PA, Kist M, Pahl HL. A secreted/shed product of Helicobacter pylori activates transcription factor nuclear factor-kappa B. J Immunol 1997;159:6140-7.

108. Müller-Decker K, Fürstenberger G. The cyclooxygenase-2mediated prostaglandin signaling is causally related to epithelial carcinogenesis. Mol Carcinog 2007;46:705-10.

109. Gudis K, Tatsuguchi A, Wada K, Futagami S, Nagata K, Hiratsuka T, Shinji Y, Miyake K, Tsukui T, Fukuda Y, Sakamoto C. Microsomal prostaglandin E synthase (mPGES)-1, mPGES-2 and cytosolic PGES expression in human gastritis and gastric ulcer tissue. Lab Invest 2005;85:225-36.

110. Oshima H, Oshima M, Inaba K, Taketo MM. Hyperplastic gastric tumors induced by activated macrophages in COX-2/ mPGES-1 transgenic mice. EMBO J 2004;23:1669-78.

111. Leung WK, To KF, Go MY, Chan KK, Chan FK, Ng EK, Chung SC, Sung JJ. Cyclooxygenase-2 upregulates vascular endothelial growth factor expression and angiogenesis in human gastric carcinoma. Int J Oncol 2003;23:1317-22.

112. Li HJ, Reinhardt F, Herschman HR, Weinberg RA. Cancerstimulated mesenchymal stem cells create a carcinoma stem cell niche via prostaglandin E2 signaling. Cancer Discov 2012;2:84055.

113. Vermeulen L, De Sousa E Melo F, van der Heijden M, Cameron K, de Jong JH, Borovski T, Tuynman JB, Todaro M, Merz C, Rodermond H, Sprick MR, Kemper K, Richel DJ, Stassi G, Medema JP. Wnt activity defines colon cancer stem cells and is regulated by the microenvironment. Nat Cell Biol 2010;12:46876. 